The $2^{\text {nd }}$ Conference on Innovation and Industrial Applications (CINIA 2016)

\title{
Pemetaan Infrastruktur Dasar dan Lingkungan Masyarakat Di Sekitar Kampus ITS Surabaya
}

\author{
Setiawan1, Eddy S. Soedjono2, Soedarso3 \& Jauhara Rana Budiani4 \\ ${ }^{1}$ Ketua Pusat Studi PDPM-LPPM ITS, FMIPA, Statistika, ITS ${ }^{2}$ Dosen Teknik Lingkungan, FTSP, Teknik \\ Lingkungan, Statistika, ITS ${ }^{3}$ Dosen UPT Soshum, UPT Soshum, ITS \\ ${ }^{4}$ Mahasiswa S2 Statistika, FMIPA, Statistika, ITS setiawantoha@yahoo.com
}

\begin{abstract}
Abstrak
Aktivitas yang dilakukan oleh ITS sebagai kampus secara langsung maupun tidak langsung akan memberikan dampak bagi masyarakat di sekitarnya baik dari segi ekonomi, sosial, budaya, dan lain-lain. Sebagai bentuk pengabdian kepada masyarakat sekitar, maka ITS melakukan kegiatan corporate social responsibility (CSR). Penelitian ini bertujuan mengidentifikasi kebutuhan dan harapan masyarkat serta persoalan infrastruktur dasar dan lingkungan di daerah sekitar lokasi kampus yang nantinya akan digunakan untuk acuan penyusunan roadmap CSR ITS. Metode yang dilakukan adalah survei in depth interview kepada RT/ aparat kelurahan di Kelurahan Gebang, Keputih, dan Kejawan Putih Tambak; FGD; dan analisis menggunakan statistika deskriptif. Berdasarkan hasil survei sarana prasarana yang terdapat di tiga kelurahan sudah memiliki fasilitas umum yang cukup, namun diperlukan perbaikan dan renovasi. Selain itu, terdapat beberapa wilayah kumuh di Keputih dan Kejawan Putih Tambak, di samping itu juga pernah terjadi banjir dan kebakaran di salah satu Kelurahan tersebut. Dari hasil tersebut, maka beberapa usulan program adalah Kampung Tahan Bencana, dan Kampung Berkelanjutan.
\end{abstract}

Kata kunci: CSR ITS, Analisis Deskriptif, Program Unggulan, Pemetaan Infrastruktur

\section{PENDAhuluan}

Perguruan tinggi adalah tingkatan tertinggi dalam bidang pendidikan yang behubungan langsung dengan masyarakat. Pada RI No. 20 tahun 2003 tentang Sistem Pendidikan Nasional dijabarkan bahwa perguruan tinggi berkewajiban menyelenggarakan Tri Dharma Perguruang Tinggi yaitu Pendidikan, Penelitian dan Pengabdian Masyarakat. Berdasarkan Undang-Undang tersebut, maka pelibatan dan pengembangan masyarakat (community involvement and development) memiliki peran penting dalam keberlanjutan kampus. Semakin besar peranan kampus untuk memberikan dampak positif terhadap masyarakat dan lingkungan dimana mereka beroperasi, dimana salah satu elemen kunci dari proses tanggung jawab sosial tersebut adalah pengembangan masyarakat. Pendekatan yang umum dilakukan dalam pengembangan masyarakat adalah memberikan program kepada masyarakat melalui kemitraan dengan organisasi non pemerintah ataupun melalui program pendampingan kelompok masyarakat.

Institut Teknologi Sepuluh Nopember (ITS) Surabaya merupakan perguruan tinggi yang berbatasan langsung dengan 3 (tiga) kelurahan yaitu Kelurahan Keputih, Gebang Putih, dan Kejawan Putih Tambak. Aktivitas yang dilakukan oleh penghuni kampus secara langsung maupun tidak langsung akan memberikan dampak bagi masyarakat di ketiga kelurahan tersebut baik dari segi ekonomi, sosial, budaya, dan lain-lain. Sebagai bentuk pengabdian kepada masyarakat sekitar, maka ITS secara perlahan-lahan bermaksud untuk mengadopsi sistem yang sudah dilakukan oleh perusahaan yaitu corporate social responsibility (CSR). Sistem corporate social responsibility (CSR) akan disesuaikan dengan kondisi perguruan tinggi yang telah populer disebut campus social responsibiliy (CSR). Sebagai dasar pembuatan program CSR, ITS perlu menjaring langsung aspirasi masyarakat sekitar. Perlu ada kerjasama aktif dari segala pihak baik dari dosen, karyawan, mahasiswa, komunitas setempat, masyarakat secara luas, pemerintah, dan kelompok lainnya. Dalam penelitian ini diharapkan akan ada hubungan timbal balik yang postif dari ITS dan juga masyarakat untuk meningkatkan kualitas hidup masyarakat di sekitar ITS. Peningkatan kualitas hidup masyarakat bukan hanya dari pembangunan infrastruktur baru yang ada wilayah masingmasing, namun juga perbaikan lingkungan seperti sanitasi dan kesehatan.

Sebagai salah satu perguruan tinggi yang memiliki kepedulian terhadap perkembangan wilayah di sekitarnya, maka ITS perlu menggali lebih dalam potensi-potensi (Sumber Daya Manusia, ekonomi, Sumber Daya Alam) yang dapat dikembangkan. Dari penelitian ini diharapkan dapat memetakan kebutuhan dan keinginan masyarakat di Kelurahan Keputih, Gebang Putih, dan Kejawan Putih Tambak terkait dengan pengembangan kampus ITS terutama pada aspek infrastruktur dan lingkungan. 


\section{TINJAUAN PUSTAKA}

\section{A. CORPORATE SOCIAL RESPONSIBILITY (CSR)}

Konsep tanggung jawab sosial perusahaan (corporate social responsibility: CSR) sangat berkaitan erat dengan konsep sustainability development (pembangunan yang berkelanjutan). Adanya konsep CSR mewajibkan perusahaan untuk memiliki tanggung jawab terhadap pihak-pihak lain, seperti: karyawan, supplier, konsumen, komunitas setempat, masyarakat secara luas, pemerintah, dan kelompok lainnya. Pelaksanaan CSR di Indonesia lebih sering dipahami sebagai upaya pengembangan masyarakat (community development) oleh perusahaan, yang diperuntukkan untuk masyarakat di sekitar lokasi perusahaan.

Pengertian CSR berdasrkan ISO 26000 adalah tanggung jawab sebuah organisasi terhadap masyarakat dan lingkungan atas dampak dari keputusan dan aktivitas yang dilakukan, melalui perilaku yang etis dan transparan dalam berkontribusi terhadap pembangunan berkelanjutan, kesehatan dan kesejahteraan masyarakat, dengan mempertimbangkan harapan stakeholder, dimana dalam pelaksanaannya memenuhi aturan yang berlaku dan konsisten terhadap norma internasional dan terintegrasi dalam keseluruhan bagian organisasi. Kesepakatan dalam ISO 26000 mencakup 7 subyek inti dalam CSR, melipui:

1. Tata kelola perusahaan (organizational governance), yaitu sistem pengambilan dan penerapan keputusan perusahaan dalam rangka pencapaian tujuannya;

2. HAM (human right), merupakan hak dasar yang berhak dimiliki semua orang sebagai manusia yang mencakup hak sipil, politik, ekonomi, social dan budaya;

3. Ketenagakerjaan (labour practices), segala kebijakan dan praktek yang terkait dengan pekerjaan yang dilakukan oleh perusahaan;

4. Lingkungan (the environment), mencakup dampak keputusan dan kegiatan perusahaan terhadap lingkungan;

5. Prosedur operasi yang wajar (fair operating procedures), merupakan perilaku etis organisasi saat berhubungan dengan organisasi dan individu lain;

6. Isu konsumen (consumer issue), yaitu tanggung jawab perusahaan penyedia barang/ jasa terhadap konsumen dan pelanggannya serta

7. Pelibatan dan pengembangan (community involvement and development) yaitu hubungan organisasi dengan masyarakat di sekitar wilayah operasinya.

Berdasarkan berbagai macam definisi-definisi yang telah disampaikan, hanya berisikan mengenai konsep pelaksanaan CSR dan belum ada suatu kebijakan yang memuat bagaimana CSR tersebut dikelola, baik oleh pemerintah, perusahaan maupun masyarakat. Selain itu, masing-masing konsep mempunyai tujuan dan sasaran yang berbeda, meskipun tidak sepenuhnya (masih beririsan). Benang merah yang dapat diambil dari berbagai definisi tersebut adalah, bahwa CSR merupakan suatu program tanggung jawab sosial berlandaskan triple bottom line (profit, people, planet) oleh dan untuk seluruh stakeholder yang dilakukan untuk menjamin keberlanjutan pembangunan. Selain itu, dalam proses menjamin keberlanjutan pembangunan tersebut, ketrlibatan masyarakat yang menjadi bagian dari entitas perusahan mempunyai peran yang cukup penting karena bepengaru terhadap kelancaran operasional perusahaan.

\section{B. INFRASTRUKTUR DASAR}

Keberhasilan dan kemajuan kelompok masyarakat tergantung pada infrastruktur fisik untuk pendistribusian sumber daya dan pelayanan publik. Kualitas dan efisiensi infrastruktur mempengaruhi kualitas hidup kesehatan sistem sosial dan keberlanjutan kegiatan perekonomian dan bisnis [1].

Menurut Suripin (2004) infrastruktur perkotaan adalah bangunan atau fasilitas-fasilitas dasar, peralatan-peralatan, instalasi-instalasi yang dibangun dan dibutuhkan untuk mendukung berfungsinya suatu sistem tatanan kehidupan sosial ekonomi masyarakat. Infrastruktur merupakan aset fisik yang dirancang dalam sistem sehingga mampu memberikan pelayanan prima pada masyarakat [2].

Infrastruktur menurut Peraturan Presiden No. 75 Tahun 2014 infrastruktur dibagi menjadi sembilan jenis transportasi, jalan, pengairan, air minum, air limbah, persampahan, telekomunikasi dan informatika, ketenagalistrikan, serta minyak dan gas bumi. Perlu dilakukan survey untuk mengetahui infrastruktur apa saja yang diperlukan masyarakat sekitar kampus ITS.

\section{PENELITIAN SEBELUMNYA}

Desi (2014) telah melakukan penelitian mengenai Optimalisasi pelaksanaan community development (CD) dalam sistem manajemen terpadu, dalam penelitiannya menjelaskan bahwa community development merupakan bagian dari CSR yaitu suatu implementasi tanggung jawab perusahaan terhadap masyarakat dimana perusahaan tersebut beroperasi. Diperlukan kebijakan tertulis yang memuat komitmen perusahaan dalam melaksanakan CD, selain itu juga menentukan cakupan wilayahdan bidang program yang akan dijalankan, peningkatan kapasitas SDM untuk meningkatkan kemampuan berkomunikasi dengan masyarakat, pemetaan yang memuat identifikasi kebutuhan masyarakat [3].

Tri Nalarsih (2007) melakukan penelitian mengenai analisis ketersediaan dan kapasitas pemenuhan infrastruktur di kawasan bisnis Benteng Surakarta. Penelitian yang dilakukannya bertujuan untuk mengidentifikasi ketersediaan dan menganalisis kapasitas pemenuhan infrastruktur; jalan, air bersih, persampahan, drainase, listrik dan telekomunikasi di kawasan bisnis Beteng Surakarta, berdasarkan pendapat responden dan perhitungan kapasitas pemenuhan. Dalam penelitiannya menjelaskan bahwa infrastruktur merupakan komponen dasar yang sangat diperlukan untuk mendukung 
kehidupan suatu Kawasan, dan infrastruktur sebagai bangunan dasar yang sangat penting dalam suatu ruang terbangun, dan ketersediaan setiap infrastruktur sangat berpengaruh terhadap pengendalian tata guna lahan (land use) Kawasan tersebut [4].

Alshuwaikhat dan Abubakar (2008) melakukan penelitian tentang kebutuhan untuk mencapai universitas yang berkelanjutan, dalam penelitiannya menjabarkan bahwa terdapat 3 (tiga) pendekatan yang ditawarkan untuk mencapai kampus yang berkelanjutan yaitu (1) University environmental management system (EMS), (2) partisipasi masyarakat \& tanggung jawab sosial, (3) kegiatan belajar mengajar yang bekerlanjutan dan riset [5].

\section{METODE PENELITIAN}

Data yang dikumpulkan pada tahap ini adalah data primer dan sekunder. Pengumpulan data sekunder akan diambil dari data demografi kelurahan dan peta-peta administrasi. Sedangkan data primer diperoleh melalui IDI (in depth interview), observasi lapangan, dan FGD (Focus Group Discussion) dengan informasi yang diperlukan terkait dengan permasalahan dan kebutuhan masyarakat khususnya dalam infrastruktur dan lingkungan. Obyek penelitian adalah kelurahan di sekitar kampus ITS yaitu Kelurahan Keputih, Kelurahan Gebang Putih, dan Kelurahan Kejawan Putih Tambak. Analisis yang digunakan adalah analisis statistika deskriptif, skoring, dan analisis konten.

\section{HASIL DAN PEMBAHASAN}

\subsection{ANALISIS KARAKTERISTIK WILAYAH}

Karakteristik wilayah didapatkan berdasarkan data sekunder maupun survei lapangan. Data sekunder diperoleh dari data publikasi Badan Pusat Statistik (BPS) dan data monografi desa. Sedangkan survei dilakukan dengan in dept interview ke pada responden yaitu tokoh masyarakat maupun pihak kelurahan, selain itu juga dilakukan survei eksplorasi langsung. Untuk memudahkan analisis hasil survei, karakteristik wilayah di bagi menjadi tiga aspek yaitu aspek sosial ekonomi, aspek infrastruktur, dan potensi pengembangan. Dalam penelitian ini difokuskan pada analisis aspek infrastruktur. Kemudian dilakukan analisis skoring untuk penilaian karakteristik wilayah masing-masing aspek. Analisis skoring digunakan untuk membandingkan antar kelurahan. Analisis skoring dilakukan berdasarkan indikator yang telah ditentukan sebagai parameter penilaian. Berikut merupakan indikator penilaian aspek infrastruktur.

Tabel 1. Jumlah dan Indikator Standar Pelayanan Sarana Prasarana Kelurahan Keputih

\begin{tabular}{c|l}
\hline Skor & \multicolumn{1}{c}{ Indikator Infrastruktur } \\
\hline \multirow{2}{*}{$\mathbf{1}$} & $\begin{array}{l}\text { 1. Tingkat keterlayanan pendidikan rendah (tidak ada bangunan sekolah ) } \\
\text { 2. Tingkat keterlayanan kesehatan rendah (tidak ada infrastruktur kesehatan) } \\
\text { 3. Tingkat permasalahan dan isu lingkungan tinggi (tidak ada RTH, ada lingkungan yang } \\
\text { kumuh, sampah belum dikelola, BABs) }\end{array}$ \\
\hline \multirow{2}{*}{$\mathbf{3}$} & $\begin{array}{l}\text { 1. Tingkat keterlayanan pendidikan sedang (bangunan sekolah ada, belum cukup) } \\
\text { 2. Tingkat keterlayanan kesehatan sedang (ada belum cukup) }\end{array}$ \\
& $\begin{array}{l}\text { 2. Tingkat permasalahan dan isu lingkungan sedang (tidak ada RTH, ada lingkungan kumuh, } \\
\text { sampah dikelola, BABs) }\end{array}$ \\
\hline
\end{tabular}

\section{Kelurahan Keputih}

Sarana dan prasarana atau fasilitas umum merupakan faktor yang mendukung kesejarteraan masyarakat. Fasilitas umum yang terdapat di Kelurahan Keputih cukup memadahi. Berikut ini ditunjukkan data sarana dan prasarana yang terdapat di Kelurahan Keputih. Selain itu juga ditunjukkan pada Tabel 3.1 apakah sarana dan prasarana yang ada sudah memenuhi standar minimal pelayanan. Standar pelayanan minimal mengacu pada Keputusan Menteri Permukiman dan Prasarana Wilayah No. 534/KPTS/M/2001 mengenai Pedoman Standar Pelayanan Minimal dan UU No. 26 Tahun 2007 tentang Penataan Ruang. 
Tabel 2. Jumlah dan Indikator Standar Pelayanan Sarana Prasarana Kelurahan Keputih

\begin{tabular}{|c|c|c|c|c|}
\hline Fasilitas & SPM & $\begin{array}{c}\text { Perhitungan } \\
\text { SPM }\end{array}$ & Jumlah & Keterangan \\
\hline \multicolumn{5}{|l|}{ Pendidikan } \\
\hline $\mathrm{KB} / \mathrm{TK}$ & 1 unit TK untuk 1.000 jiwa & 16 & 15 & Tidak Terpenuhi \\
\hline $\mathrm{SD}$ & 1 unit SD untuk 6.000 jiwa & 3 & 6 & Terpenuhi \\
\hline SMP & 1 unit SMP untuk 25.000 & 1 & 2 & Terpenuhi \\
\hline SMA & 1 unit SMA untuk 30.000 & 1 & 4 & Terpenuhi \\
\hline Pondok Pesantren & - & - & 1 & \\
\hline \multicolumn{5}{|l|}{ Kesehatan } \\
\hline Rumah Sakit & \multirow{4}{*}{$\begin{array}{l}1 \text { Unit Balai Pengobatan/ } \\
3.000 \text { jiwa }\end{array}$} & \multirow{4}{*}{5} & 2 & \multirow{4}{*}{ Terpenuhi } \\
\hline Puskesmas & & & 1 & \\
\hline Poliklinik & & & 1 & \\
\hline Posyandu & & & 16 & \\
\hline $\begin{array}{l}\text { Lingkungan } \\
\text { Ruang Terbuka } \\
\text { Hijau/Taman } \\
\end{array}$ & $\begin{array}{l}30 \% \text { dari luas wilayah (UU } \\
\text { No. } 26 \text { Tahun 2007) }\end{array}$ & $567,3 \mathrm{Ha}$ & $4.4 \mathrm{Ha}$ & Tidak Terpenuhi \\
\hline \multicolumn{5}{|l|}{ Tempat Ibadah } \\
\hline Masjid & \multirow[t]{2}{*}{ minimal 1 unit tempat ibadah } & & 11 & \multirow{2}{*}{ Terpenuhi } \\
\hline Musholla & & 1 & 28 & \\
\hline
\end{tabular}

Berdasarkan data sarana prasarana yang telah didapatkan, ditunjukkan pada Tabel 3.1, sebagian besar faasilitas sarana prasarana Kelurahan Keputih sudah terpenuhi. Akan tetapi terdapat fasilitas yang belum terpenuhi, jika di bandingkan dengan jumlah warga di Keputih fasilitas pendidikan KB/TK kurang satu unit. Selain itu juga ruang terbuka hijau atau RTH di Keputih masih kurang.
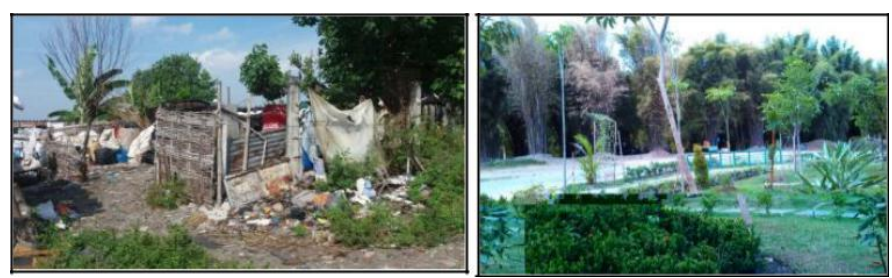

Gambar 1. (a) Wilayah Kumuh Kelurahan Keputih, (b) Taman Sakura Kelurahan Keputih

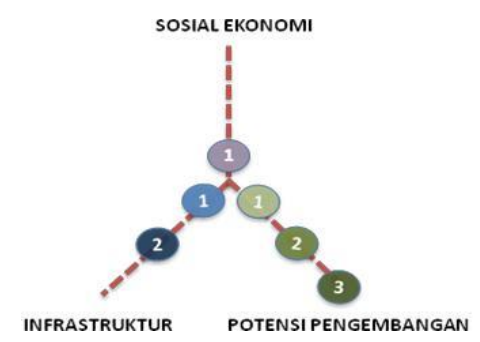

Gambar 2. Diagram Analisis Penilaian Karakteristik Wilayah Keputih

Kondisi pemukiman di Kelurahan Keputih masih terdapat wilayah yang tergolong kumuh, terutama di bekas TPA keputih. Kelurahan Keputih terdapat wilayah kumuh di sekitar bekas TPA, meskipun TPA sudah tidak digunakan lagi, tetapi masih ada wilayah pengepul sampah di wilayah tersebut. Sampah-sampah terlihat berserakan, sehingga wilayah tersebut terlihat kumuh.

Berdasarkan survei yang dilakukan, masih ditemukan warga yang melakukan BAB sembarangan. Di kelurahan Keputih terdapat $14,3 \%$ warga yang menyatakan terdapat warga yang masih BAB sembarangan. Responden menyatakan bahwa warga melakukan BAB sembarangan terutama di daerah tanah lapang atau di sungai. Di Kelurahan Keputih warga yang msih BAB sembarangan dikarenakan masih ada yang belum memiliki jamban.

Kelurahan Keputih memiliki Taman Sakura yang menjadi ruang terbuka hijau. Luas taman cukup luas, tetapi pengembangannya belum maksimal, banyak lahan yang belum dimanfaatkan. Pemanfaatan hanya sebatas rekreatif, belum pemanfaatan yang produktif. Selain memiliki taman, di keputih juga terdapat potensi mangrove yang bisa dikembangkan sebagai tempat wisata. Akan tetapi masih dibutuhkan akses yang atau jalan untuk mempermudah menuju lokasi mangrove keputih. 


\section{Kelurahan Gebang Putih}

Luas Kelurahan Gebang tidak seluas Kelurahan Keputih, sehingga fasilitas umum yang ada di Gebang tidak sebanyak di Keputih. Berdasarkan data monografi desa fasilitas peribadatan di Kelurahan Gebang ada 5 masjid dan 5 mushola. Untuk aktivitas ekonomi terdapat satu pasar sebagai pusat aktivitas ekonomi. Fasilitas kesehatan yang terdapat di Kelurahan gebang yaitu ada puskesmas pembantu, poliklinik, apotek, dan posyandu. Fasilitas pendidikan terdapat lima TK, tiga SD, pondok pesantren, dan SLB YPAB. Sedangkan sekolah SMP dan SMA tidak terdapat di Kelurahan Gebang. Pada tabel 3.2 di tunjukkan fasilitas sarana prasarana yang ada di Gebang Putih dan i ndikator Standar Pelayanan Minimal, sehingga dapat diketahui apakah fasilitas sarana prasarana di Gebang Putih sudah terpenuhi atau belum.

Tabel 3. Jumlah dan Indikator Standar Pelayanan Sarana Prasarana Kelurahan Gebang Putih

\begin{tabular}{|c|c|c|c|c|}
\hline Fasilitas & SPM & $\begin{array}{l}\text { Perhitungan } \\
\text { SPM }\end{array}$ & Jumlah & Keterangan \\
\hline \multicolumn{5}{|l|}{ Pendidikan } \\
\hline $\mathrm{KB} / \mathrm{TK}$ & 1 unit TK untuk 1.000 jiwa & 8 & 5 & Tidak Terpenuhi \\
\hline SD & 1 unit SD untuk 6.000 jiwa & 1 & 3 & Terpenuhi \\
\hline SMP & 1 unit SMP untuk 25.000 & - & - & - \\
\hline SMA & 1 unit SMA untuk 30.000 & - & - & - \\
\hline Pondok Pesantren & - & & 1 & - \\
\hline \multicolumn{5}{|l|}{ Kesehatan } \\
\hline Rumah Sakit & & 3 & - & \multirow{4}{*}{ Terpenuhi } \\
\hline Puskesmas Pembantu & 1 Unit Balai & & 1 & \\
\hline Poliklinik & Pengobatan $/ 3.000$ jiwa & & 2 & \\
\hline Posyandu & & & 4 & \\
\hline \multicolumn{5}{|l|}{ Ruang Terbuka Hijau } \\
\hline Taman & \multicolumn{2}{|l|}{$\begin{array}{l}30 \% \text { dari luas wilayah } \\
\text { (UU No. } 26 \text { Tahun 2007) }\end{array}$} & 0 & Tidak Terpenuhi \\
\hline \multicolumn{5}{|l|}{ Temapt Ibadah } \\
\hline $\begin{array}{l}\text { Masjid } \\
\text { Musholla }\end{array}$ & minimal 1 unit tempat ibadah & 1 & $\begin{array}{l}5 \\
5\end{array}$ & Terpenuhi \\
\hline
\end{tabular}
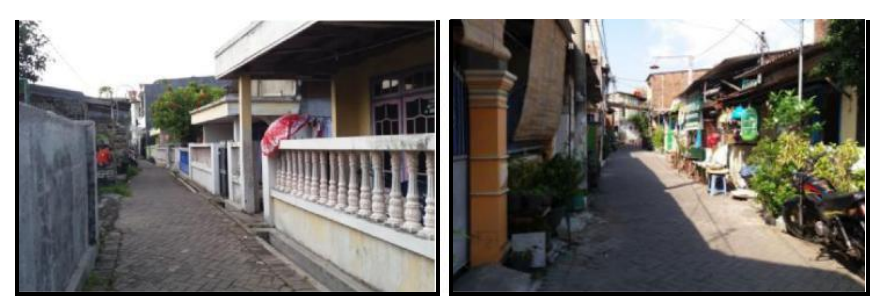

Gambar 3. Kondisi Pemukiman Kelurahan Gebang Putih

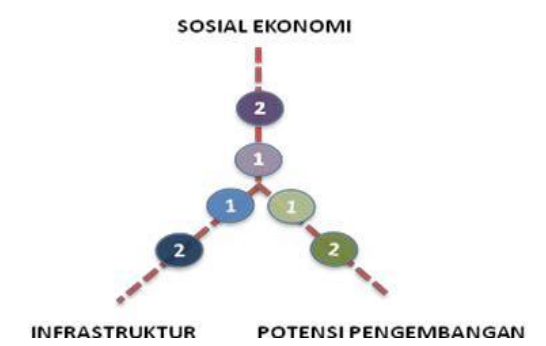

Gambar 4. Diagram Analisis Penilaian Karakteristik Wilayah Gebang Putih

Berdasarkan survei yang dilakukan, masih ditemukan warga yang melakukan BAB sembarangan. Di Kelurahan Gebang terdapat $8,3 \%$ responden yang telah di survei menyatakan bahwa terdapat warganya yang masih berperilaku $\mathrm{BAB}$ sembarangan. Sedangkan di Kelurahan Gebang, wilayah kumuh karena sampah berserakan tidak terlihat. Tetapi Kelurahan Gebang merupakan wilayah sangat padat dengan kepadatan melebihi kepadatan Kecamatan Sukolilo.

\section{Kelurahan Kejawan Putih Tambak}

Berdasarkan data monografi desa dan hasil survei di lapangan Kelurahan Kejawan Putih Tambak memiliki fasilitas umum yang cukup lengkap. Terdapat fasilitas peribadatan yaitu tiga masjid dan enam mushola. Kegiatan ekonomi terdapat pusat perbelanjaan di wilayah Pakuwon City, selain itu juga terdapat banyak toko-toko kelontong dan warung makan. Fasilitas kesehatan yang ada di Kejwan Putih Tambak belum lengkap, hanya ada laboratorium dan apotek. Sedangkan puskesmas atau klinik belum ada. Pada fasilitas pendidikan cukup lengkap dari TK hingga perguruan tinggi ada di Kelurahan Kejawan Putih Tambak. Pada Tabel 3.3 di sajikan data sarana dan prasarana di Kejawan Putih Tambak serta indikator standar pelayanan minimal.

Tabel 4. Jumlah dan Indikator Standar Pelayanan Sarana Prasarana Kelurahan Kejawan Putih Tambak 


\begin{tabular}{|c|c|c|c|c|}
\hline Fasilitas & SPM & $\begin{array}{c}\text { Perhitungan } \\
\text { SPM }\end{array}$ & Jumlah & Keterangan \\
\hline \multicolumn{5}{|l|}{ Pendidikan } \\
\hline $\mathrm{KB} / \mathrm{TK}$ & 1 unit TK untuk 1.000 jiwa & 6 & 6 & \multirow{5}{*}{ Terpenuhi } \\
\hline SD & 1 unit SD untuk 6.000 jiwa & 1 & 3 & \\
\hline SMP & 1 unit SMP untuk 25.000 & 1 & 2 & \\
\hline SMA & 1 unit SMA untuk 30.000 & 1 & 2 & \\
\hline Pondok Pesantren & - & & 1 & \\
\hline \multicolumn{5}{|l|}{ Kesehatan } \\
\hline Rumah Sakit & & \multirow{4}{*}{2} & - & \multirow[t]{4}{*}{ Tidak Terpenuhi } \\
\hline Puskesmas Pembantu & 1 Unit Balai & & - & \\
\hline Poliklinik & Pengobatan $/ 3.000$ jiwa & & - & \\
\hline Posyandu & & & - & \\
\hline \multicolumn{5}{|l|}{ Ruang Terbuka Hijau } \\
\hline Taman & $\begin{array}{l}30 \% \text { dari luas wilayah (UU } \\
\text { No. } 26 \text { Tahun } 2007 \text { ) }\end{array}$ & & & Tidak terpenui \\
\hline \multicolumn{5}{|l|}{ Temapt Ibadah } \\
\hline Masjid & minimal 1 unit tempat & 1 & 3 & Terpenuhi \\
\hline Musholla & ibadah & & 6 & \\
\hline
\end{tabular}

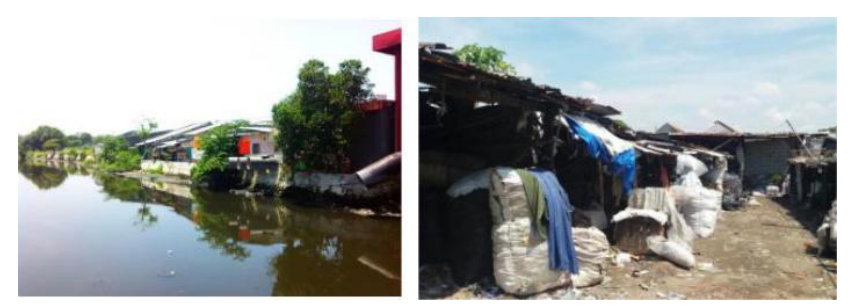

Gambar 5. (a) Rumah Tidak Memiliki Saptic Tank, (b) Wilayah Pemulung di Kejawan Putih Tambak SOSIAL EKONOMI

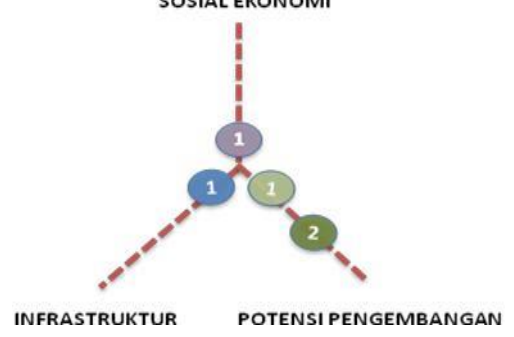

Gambar 6. Diagram Analisis Penilaian Karakteristik Wilayah Gebang Putih

Di Kelurahan Kejawan Putih Tambak responden yang menyatakan bahwa masih ada warga yang melakukan BAB sembarangan yaitu 27,6\%. Responden menyatakan bahwa warga melakukan BAB sembarangan terutama di daerah tanah lapang atau di sungai. Terdapat warga yang memiliki jamban tetapi tidak memilki septic tank. Masih terdapat wilayah kumuh di Kejawan putih tambak, terutama di wilayah pemulung sampah plastik, sehingga sampah-sampah berserakan disekitar wilayah tersebut. Selain itu juga terdapat gerobak sampah di pinggir jalan utama yang tidak ada lahan pasti untuk menempatkan gerobak sampah.

\section{(1) ANALISIS SWOT TERHADAP KARAKTERISTIK WILAYAH}

Setelah mengetahui karakteristik infrastruktur dan lingkungan wilayah, selanjutnya dilakukan analisis SWOT untuk mengetahui strategi yang harus dilakukan. Analisis SWOT merupakan analisis yang menemukan srength (kekuatan), weakness (kelemahan), opportunity (peluang), dan threat (ancaman) di setiap wilayah. Hasil strategi yang disusun berdasarkan analisis SWOT setiap kelurahan ditampilkan pada Tabel. Sedangkan analisis SWOT setiap kelurahan terdapat pada Lampiran. 


\begin{tabular}{|c|c|c|c|c|}
\hline \multirow{2}{*}{\multicolumn{2}{|c|}{$\begin{array}{c}\text { SWOT } \\
\text { STRATEGIES }\end{array}$}} & \multicolumn{3}{|c|}{ Internal Analysis } \\
\hline & & Strengths & \multicolumn{2}{|l|}{ Weaknesses } \\
\hline & Opportunity & $\begin{array}{l}\text { - Pengembangan Kawasan } \\
\text { Pesisir }\end{array}$ & $\begin{array}{l}\text { - Peningkatan Kualitas } \\
\text { Masyarakat Sekitar }\end{array}$ & Hidup \\
\hline $\begin{array}{l}\text { Eksternal } \\
\text { Analysis }\end{array}$ & Threat & $\begin{array}{l}\text { - Menciptakan lingkungan yang } \\
\text { aman dan resiliens terhadap } \\
\text { kerawanan bencana }\end{array}$ & $\begin{array}{l}\text { - Peningkatan Kualitas } \\
\text { Masyarakat Sekitar }\end{array}$ & Hidup \\
\hline
\end{tabular}

Usulan program CSR aspek infrastruktur dasar dan ingkungan yang dapat dilaksanakan berdasarkan strategi yang disusun adalah program ODF, penyediaan sistem persampahan, perbaikan fasilitas umum, dan pengembangan wisata mangrove.

\section{KESIMPULAN}

Berdasarkan tujuan penelitian dan hasil analisis, maka kesimpulan dalam penelitian ini adalah.

a. Fasilitas sarana dan prasarana di Kelurahan Keputih dan Gebang Putih hanya fasilitas sekolah TK/KB dan ruang terbuka hijau atau taman yang masih belum terpenuhi. Di Kelurahan Kejawan Putih Tambak yang tidak terpenuhi adalah fasilitas kesehatan dan ruang terbuka hijau

b. Kondisi lingkungan di ketiga kelurahan masih terdapat warga yang berperilaku BAB sembarangan, masih terdapat wilayah kumuh di Kelurahan Keputih dan Kejawan Putih Tambak, sedangkan di Kelurahan Gebang Putih merupakan permukiman padat penduduk.

c. Di kelurahan Keputih terdapat potensi yang dapat dikembangkan, yaitu taman Sakura dan dan wisata mangrove.

d. Hasil skoring di ketiga kelurahan menunjukan bahwa kelurahan Kejawan Putih Tambak yang paling rendah dalam hal infrastruktur dan lingkungan.

e. Hasil analisis strategi dari analisis SWOT untuk aspek infrastruktur dan lingkungan adalah sebagai berikut.

i. Pengembangan Kawasan Pesisir

ii. Menciptakan lingkungan yang aman dan resiliens terhadap kerawanan bencana

iii. Peningkatan Kualitas Hidup Masyarakat Sekitar

\section{DAFTAR PUSTAKA}

[1] W. R. Hudson, R. C. G. (Ralph C. G. . Haas, and W. Uddin, Infrastructure management : integrating design, construction, maintenance, rehabilitation, and renovation. McGraw-Hill, 1997.

[2] M. E. D. I. Suripin, Drainase Perkotaan yang Berkelanjutan. Yogyakarta: ANDI OFFSET, 2004.

[3] D. CAHYANINGTYAS and DESI, "OPTIMALISASI PELAKSANAAN COMMUNITY DEVELOPMENT DALAM SISTEM MANAJEMEN TERPADU,” Pap. Present. Ind. Eng. RTI 307.14 Cah o, 2014, 2014.

[4] R. Tri Nalarsih, "Analisis Ketersediaan Dan Kapasitas Pemenuhan Infrastruktur Di Kawasan Bisnis Beteng Surakarta," Universitas Diponegoro.

[5] H. M. Alshuwaikat and I. Abubakar, "An integrated approach to achieving campus sustainability: assessment of the current campus environmental management practices," J. Clean. Prod., vol. 16, no. 16, pp. 1777-1785, Nov. 2008. 